\title{
NEFL Gene
}

National Cancer Institute

\section{Source}

National Cancer Institute. NEFL Gene. NCI Thesaurus. Code C88041.

This gene is involved in the structure of neuronal processes. 